\title{
Hubungan Sikap dan Karakteristik Pasangan Usia Subur (PUS) dengan Keikutsertaan dalam Program KB di Wilayah Kerja UPT Puskesmas Sungai Raya Kecamatan Sungai Raya Kabupaten Aceh Timur Tahun 2018
}

\author{
Relationship of Attitude and Charecteristic of Fertile Age Couple (PUS) with \\ The Absent in Contraception Program in Work Area of UPT of Sungai Raya \\ Local Government Clinic Sungai Raya Subdistrict Aceh Timur Regency In \\ 2018
}

\author{
Ainul Mardhiah', Aminy*2 \\ ${ }^{1,2}$ Program Studi Diploma III Akademi Kebidanan Harapan Ibu Langsa \\ *Korespondensi Penulis: ukhtiaminy90@gmail.com
}

\begin{abstract}
Abstrak
Program KB juga bertujuan untuk meningkatkan kualitas keluarga agar dapat timbul rasa aman, tentram, dan harapan masa depan yang lebih baik dalam mewujudkan kesejahteraan lahir dan kebahagiaan batin. Diduga faktor yang menyebabkan ketidakikutsertaan PUS dalam program KB adalah karakteristik. Tujuan penelitian ini untuk mengetahui hubungan sikap dan karakteristik Pasangan Usia Subur (PUS) dengan keikutsertaan dalam program KB di Wilayah Kerja UPT Puskesmas Sungai Raya Kecamatan Sungai Raya Kabupaten Aceh Timur tahun 2018. Desain penelitian yang digunakan adalah survei analitik dengan rancangan bedah lintang. Populasi dari penelitian ini adalah seluruh Pasangan Usia Subur yang berada di Wilayah Kerja UPT Puskesmas Sungai Raya pada bulan Januari sampai dengan Desember tahun 2017 yang berjumlah 1.897 orang. Pengambilan sampel menggunakan rumus Slovin, didapatkan sebanyak 95 sampel. Penelitian dilaksanakan dari tanggal 7-17 Juli tahun 2018 menggunakan kuesioner dengan cara wawancara. Uji statistik menggunakan uji chi-square. Hasil penelitian menunjukkan bahwa mayoritas Pasangan Usia Subur (PUS) ikut serta dalam program KB yaitu sebanyak 67 responden $(70,5 \%)$. Secara statistik ada hubungan sikap dan karakteristik Pasangan Usia Subur (PUS) dengan ketidakikutsertaan dalam program KB di Wilayah Kerja UPT Puskesmas Sungai Raya Kecamatan Sungai Raya Kabupaten Aceh Timur tahun 2018 dengan $p$ value $<0,1$. Sebaiknya pemegang program KB di UPT Puskesmas Sungai Raya Kecamatan Sungai Raya Kabupaten Aceh Timur agar mengajak tokoh lintas sektor agar mengadakan pertemuan untuk membuat rencana loka karya mini setidaknya satu bulan sekali untuk meningkatkan keikutsertaan Pasangan Usia Subur (PUS) dalam program KB.
\end{abstract}

Kata Kunci: Ketidakikutsertaan dalam Program KB, Sikap, Karakteristik

\section{Abstract}

Family planning program also aims to increase the quality of some family in order to get a feeling of safe, peace, and better life future in realizing the physical prosperity and soul happiness. It is presumed that the factor of the absent of Fertile Age Couple (PUS) in family planning program is characteristic. The purpose of this research is to know the relationship 
of attitude and characteristic of Fertile Age Couple (PUS) with the absent in contraception program in work area of Technical Implementation Unit (UPT) of Sungai Raya local government clinic Sungai Raya sub district Aceh Timur regency 2018. The design used in this research is analytic survey with cross sectional design. The population of this research is Fertile Age Couple (PUS) in work area Technical Implementation Unit (UPT) of Sungai Raya local government clinic from January until December 2017 in number of 1.897 persons. The choosing of the sample uses Slovin formula found that 95 samples. The research conducts at $07^{\text {th }}-17^{\text {th }}$ July 2018 using questioner by interview. Statistic test uses chi square test. The research result shows that the majority of respondents of Fertile Age Couple participates with family planning program there are 67 respondents (70,5\%).Statistically there have relationship of attitude and characteristic of Fertile Age Couple with the absent in contraception program in work area of Technical Implementation Unit (UPT) of Sungai Raya local government clinic Sungai Raya sub district Aceh Timur regency 2018 with p value $<0,1$. It is better for stakeholder of family planning at relationship of attitude and characteristic of Fertile Age Couple with the absent in contraception program in work area of Technical Implementation Unit of Sungai Raya local government clinic Sungai Raya sub district Aceh Timur regency in order to invite cross sector socialite having a discussion to arrange a mini workshop planning at least once a month to increase the participating of Fertile Age Couple in family planning program.

Keywords: the absent of contraception program, attitude, characteristic

\section{PENDAHULUAN}

Program Keluarga Berencana (KB) sangat penting dalam memungkinkan pasangan untuk menentukan apakah, kapan, berapa jumlah anak dan yang sangat penting untuk menentukan jarak kehamilan serta keluarga yang sehat. Keluarga berencana memiliki manfaat kesehatan, ekonomi, dan sosial yang mendalam bagi keluarga dan masyarakat (USAID, 2018).

Berdasarkan data yang dipublikasikan oleh Badan Pusat Statistik (BPS) pada tahun 2017 yang berjudul Statistik Indonesia 2017 (Statistical Yearbook of Indonesia 2017), jumlah penduduk Indonesia adalah sebanyak 258.704.900 jiwa pada tahun 2016. Angka tersebut lebih tinggi sekitar 8,5\% atau bertambah sebanyak 20.186.200 jiwa dibandingkan dengan tahun 2015 yang berjumlah 238.518.800 jiwa. Sepanjang tahun 2014 data menunjukkan Angka Kematian Ibu (AKI) di Indonesia mencapai 5.048 kasus. Lanjut pada tahun 2015 berkurang menjadi 4.897 kasus dan data terakhir di tahun 2016 ada 4.834 kasus. AKI di Indonesia masih sekitar 305 per 100 ribu kelahiran.

KB merupakan salah satu strategi untuk mengurangi kematian ibu khususnya ibu dengan kondisi 4T yaitu terlalu muda melahirkan (di bawah usia 20 tahun), terlalu sering melahirkan, terlalu dekat jarak melahirkan, dan terlalu tua melahirkan (di atas usia 35 tahun). 
Selain itu, program KB juga bertujuan untuk meningkatkan kualitas keluarga agar dapat timbul rasa aman, tentram, dan harapan masa depan yang lebih baik dalam mewujudkan kesejahteraan lahir dan kebahagiaan batin. Sasaran pelaksanaan program KB yaitu Pasangan Usia Subur (PUS). Pasangan Usia Subur (PUS) adalah pasangan suami-istri yang terikat dalam perkawinan yang sah, yang istrinya berusia antara 15 sampai dengan 49 tahun (Kemenkes RI, 2017).

Persentase peserta KB aktif terhadap pasangan usia subur di Indonesia pada tahun 2016 sebesar 74,8\%. Tiga provinsi yang memiliki persentase tertinggi yaitu Maluku Utara sebesar 87,03\%, Kepulauan Bangka Belitung sebesar 83,92\%, dan Sulawesi Utara sebesar 83,84\%. Sedangkan capaian terendah terdapat di Provinsi Nusa Tenggara Timur sebesar 63,24\%, Sumatera Barat sebesar 63,73\%, dan DKI Jakarta sebesar 67,46\% (Kemenkes RI, 2017).

Pencapaian peserta KB aktif semua metode di Provinsi Aceh tahun 2016 di dapatkan data dengan jumlah 625.414 peserta, dengan rincian pengguna aktif Metode Kontrasepsi Jangka Panjang (MKJP) 53.202 peserta, pengguna aktif Intra Uteri Device (IUD) 21.348 peserta, pengguna aktif Implan 23.926 peserta, pengguna aktif Metode Operasional Pria (MOP) 195 peserta, pengguna aktif Metode Operasional Wanita (MOW) 7.733 peserta, pengguna aktif kontrasepsi suntik 293.861 peserta, pengguna aktif Pil 225.566 peserta dan pengguna aktif kondom 52.785 peserta (BKKBN Provinsi Aceh, 2016).

Berdasarkan data dari Dinas Kesehatan Kabupaten Aceh Timur dapat diketahui bahwa pada tahun 2017, jumlah PUS sebesar 67.858. Penggunaan alat kontrasepsi terbanyak adalah suntik sebanyak 17.088, disusul pil sebanyak 12.351, implan sebanyak 741 dan AKDR sebanyak 618. Penggunaan alat kontrasepsi terbanyak pada tahun 2018 adalah suntik sebanyak 16.938 (Dinkes Aceh Timur, 2018).

Program KB di wilayah kerja UPT Puskesmas Sungai Raya masih belum berjalan maksimal. Hal ini dapat diketahui dari jumlah peserta KB aktif yang hanya meningkat sedikit. Pada tahun 2017, jumlah PUS di wilayah kerja Puskesmas Sungai Raya sebesar 1.897 orang dan jumlah Wanita Usia Subur (WUS) sebesar 2.824 orang. Pencapaian peserta KB aktif semua metode kontrasepsi sebesar 861 orang $(45,4 \%)$. Pencapaian tersebut masih jauh dari target yang ditetapkan Dinas Kesehatan Provinsi Aceh, yaitu sebesar 85\% dari PUS mengikuti program KB (Puskesmas Sungai Raya, 2018).

Hasil wawancara yang dilakukan peneliti pada saat survei awal kepada 10 PUS di wilayah kerja UPT Puskesmas Sungai Raya dapat diketahui bahwa 6 PUS tidak bersedia ikut 
serta dalam program KB dengan alasan tidak diijinkan oleh suami, riwayat sakit jantung, keagamaan dan berpegang pada mottonya "banyak anak banyak rejeki”. Pola fikir ortodok tersebut tentu sangat tidak baik jika ditinjau dari segi kesehatan. Program KB merupakan salah satu cara yang paling efektif untuk meningkatkan ketahanan keluarga, kesehatan, dan keselamatan ibu, anak, serta perempuan.

Secara umum faktor-faktor yang menyebabkan PUS tidak menjadi peserta KB adalah pelayanan KB yang masih kurang berkualitas, keterbatasan alat kontrasepsi, penyampaian konseling maupun KIE (Komunikasi, Informasi, dan Edukasi) belum dilaksanakan dengan baik, hambatan budaya, kelompok wanita yang sudah tidak ingin anak lagi tetapi tidak menggunakan alat kontrasepsi (unmet need), dan kelompok hard core yaitu kelompok wanita yang tidak mau menggunakan alat kontrasepsi baik pada saat ini maupun pada waktu yang akan datang. Selain itu, faktor lain yang menyebabkan ketidakikutsertaan PUS dalam program KB adalah karakteristik PUS, yaitu usia, pendidikan, pekerjaan, pendapatan, paritas, jumlah anak dan lain-lain (Dewi, 2014).

Program keluarga berencana $(\mathrm{KB})$ dilakukan untuk mengatur jumlah kelahiran atau menjarangkan kelahiran. Oleh sebab itu, dalam upaya meningkatkan kesehatan ibu, sasaran utama program KB adalah pada kelompok unmet need, dan ibu pasca persalinan. KB pasca persalinan merupakan sasaran penting serta suatu upaya strategis dalam penurunan Angka Kematian Ibu (AKI), Angka Kematian Bayi (AKB) serta penurunan Total Fertility Rate (TFR). Mengikuti program KB setelah persalinan akan mencegah kehamilan yang tidak diinginkan, menjaga dan meningkatkan kesehatan ibu, bayi dan balita serta ibu memiliki waktu dan perhatian yang cukup untuk dirinya sendiri, anak dan keluarga. Dengan demikian pelayanan keluarga berencana merupakan upaya pelayanan kesehatan preventif yang paling dasar dan utama (Darmawati, 2017).

Penelitian ini bertujuan untuk mengetahui hubungan karakteristik pasangan usia subur (PUS) dengan ketidakikutsertaan dalam program KB di wilayah kerja UPT puskesmas Sungai Raya Kecamatan Sungai Raya Kabupaten Aceh Timur Tahun 2018”.

\section{METODE PENELITIAN}

Penelitian ini bersifat survei analitik dengan rancangan cross sectional. Lokasi Penelitian di Wilayah Kerja UPT Puskesmas Sungai Raya Kecamatan Sungai Raya Kabupaten Aceh Timur Tahun 2018. Penyebaran kuesioner dilakukan pada tanggal 7-17 Juli 
tahun 2018. Populasi dalam penelitian ini adalah seluruh Pasangan Usia Subur yang berada di Wilayah Kerja UPT Puskesmas Sungai Raya pada bulan Januari sampai dengan Desember tahun 2017 yang berjumlah 1.897 orang. Besar sampel penelitian diambil sebanyak 95 pus menggunakan rumus Slovin. Adapun teknik pengambilan sampel yang dilakukan dengan cara stratified random sampling dimana setiap anggota atau unit dari populasi mempunyai kesempatan yang sama untuk diseleksi sebagai sampel. Pengambilan sampel pada masingmasing desa dilakukan dengan cara mencabut undian/lotre.

Teknik pengumpulan data terdiri dari data primer, data sekunder dan data tersier. Data primer diperoleh dari peninjauan langsung pada objek penelitian yaitu PUS, dengan melakukan penyebaran kuisioner serta melakukan wawancara pada PUS yang tinggal di wilayah kerja UPT Puskesmas Sungai Raya. Data sekunder diperoleh dari Dinas Kesehatan dan Puskesmas Sungai Raya. Sedangkan data tersier diperoleh dari buku, jurnal-jurnal kesehatan dan penelitian terdahulu yang berhubungan dengan ketidakikutsertaan PUS dalam program KB melalui internet secara online.

Data dianalisa secara univariat dan bivariat. Analisis univariat bertujuan untuk menjelaskan atau mendeskripsikan karakterisktik setiap variabel penelitian. Analisis bivariat dilakukan terhadap dua variabel yang diduga berhubungan atau berkorelasi. Untuk menyimpulkan hasil perhitungan, maka nilai $x^{2}$ dari rumus tersebut diatas, dibandingkan dengan nilai $x^{2}$ dalam tabel kai-kuadrat berdasarkan derajat kepercayaan yang dipilih dan derajat kebebasan dari data yang ada.

Hasil analisa bivariat yaitu keputusan hipotesis Ha diterima bila nilai P (P value) lebih kecil dari $\alpha$ (alpha) atau $(\mathrm{p}<0,05)$ maka keputusannya adalah menerima hipotesis Ha. Sebaliknya bila $\mathrm{P}$ value lebih besar dari alpha $(\mathrm{p}>0,05)$ maka hipotesis ditolak.

\section{HASIL PENELITIAN}

Hasil penelitian yang dilakukan terhadap 95 Pasangan Usia Subur yang berada di Wilayah Kerja UPT Puskesmas Sungai Raya dari tanggal 7-17 Juli tahun 2018 untuk mengetahui Hubungan Sikap dan Karakteristik Pasangan Usia Subur (PUS) dengan Keikutsertaan dalam Program KB di Wilayah Kerja UPT Puskesmas Sungai Raya Kecamatan Sungai Raya Kabupaten Aceh Timur Tahun 2018, data yang di peroleh dari hasil tabulasi data primer berdasarkan jawaban kuesioner dari responden didapatkan hasil sebagai berikut : 
Tabel 1. Ketidakikutsertaan Pasangan Usia Subur (PUS) dalam Program KB di Wilayah Kerja UPT Puskesmas Sungai Raya Kecamatan Sungai Raya Kabupaten Aceh Timur Tahun 2018

\begin{tabular}{cccc}
\hline No & $\begin{array}{c}\text { Ketidakikutsertaan PUS } \\
\text { dalam Program KB }\end{array}$ & $\begin{array}{c}\text { Frekuensi } \\
\text { (f) }\end{array}$ & $\begin{array}{c}\text { Persentase } \\
(\mathbf{\%})\end{array}$ \\
\hline 1 & Ya & 67 & 70,5 \\
2 & Tidak & 28 & 29,5 \\
\hline \multicolumn{2}{c}{ Total } & $\mathbf{9 5}$ & $\mathbf{1 0 0}$ \\
\hline
\end{tabular}

Sumber data primer (Diolah Tahun 2018)

Tabel di atas menunjukkan bahwa dari 95 Pasangan Usia Subur (PUS) (100\%) mayoritas ikut serta dalam program KB yaitu sebanyak 67 responden (70,5\%).

Tabel 2. Distribusi Frekuensi Sikap Pasangan Usia Subur (PUS) di Wilayah Kerja UPT Puskesmas Sungai Raya Kecamatan Sungai Raya Kabupaten Aceh Timur Tahun 2018

\begin{tabular}{cllcc}
\hline No & Sikap & $\begin{array}{c}\text { Frekuensi } \\
(\mathbf{f})\end{array}$ & $\begin{array}{c}\text { Persentase } \\
(\mathbf{\%})\end{array}$ \\
\hline 1 & Positif & & 65 & 68,4 \\
2 & Negatif & & 30 & 31,6 \\
\hline \multicolumn{2}{r}{} & Total & $\mathbf{9 5}$ & $\mathbf{1 0 0}$ \\
\hline
\end{tabular}

Sumber data primer (Diolah Tahun 2018)

Tabel di atas menunjukkan bahwa dari 95 Pasangan Usia Subur (PUS) (100\%) mayoritas bersikap positif yaitu sebanyak 65 responden $(68,4 \%)$.

Tabel 3. Distribusi Frekuensi Karakteristik Pasangan Usia Subur (PUS) di Wilayah Kerja UPT Puskesmas Sungai Raya Kecamatan Sungai Raya Kabupaten Aceh Timur Tahun 2018 Berdasarkan Usia

\begin{tabular}{clcc}
\hline No & Usia & $\begin{array}{c}\text { Frekuensi } \\
(\mathbf{f})\end{array}$ & $\begin{array}{c}\text { Persentase } \\
(\mathbf{\%})\end{array}$ \\
\hline 1 & Remaja Akhir & 27 & 28,4 \\
2 & Dewasa Awal & 25 & 26,3 \\
3 & Dewasa Akhir & 38 & 40,0 \\
4 & Lansia Awal & 5 & 5,3 \\
\hline \multicolumn{2}{c}{ Total } & $\mathbf{9 5}$ & $\mathbf{1 0 0}$ \\
\hline
\end{tabular}

Sumber data primer (Diolah Tahun 2018)

Tabel 3 menunjukkan bahwa dari 95 Pasangan Usia Subur (PUS) (100\%) mayoritas berusia dewasa akhir yaitu sebanyak 38 responden (40,0\%) dan minoritas berusia lansia awal yaitu sebanyak 5 responden $(5,3 \%)$. 
Tabel 4. Distribusi Frekuensi Karakteristik Pasangan Usia Subur (PUS) di Wilayah Kerja UPT Puskesmas Sungai Raya Kecamatan Sungai Raya Kabupaten Aceh Timur Tahun 2018 Berdasarkan Pendidikan

\begin{tabular}{clccc}
\hline No & & Pendidikan & $\begin{array}{c}\text { Frekuensi } \\
(\mathbf{f})\end{array}$ & $\begin{array}{c}\text { Persentase } \\
(\mathbf{\%})\end{array}$ \\
\hline 1 & Tinggi & 26 & 27,4 \\
2 & Menengah & 41 & 43,2 \\
3 & Dasar & 28 & 29,5 \\
\hline \multicolumn{2}{c}{ Total } & $\mathbf{9 5}$ & $\mathbf{1 0 0}$ \\
\hline
\end{tabular}

Sumber data primer (Diolah Tahun 2018)

Tabel di atas menunjukkan bahwa dari 95 Pasangan Usia Subur (PUS) (100\%) mayoritas berpendidikan menengah yaitu sebanyak 41 responden $(43,2 \%)$ dan minoritas berpendidikan tinggi yaitu sebanyak 26 responden $(27,4 \%)$.

Tabel 5. Distribusi Frekuensi Karakteristik Pasangan Usia Subur (PUS) di Wilayah Kerja UPT Puskesmas Sungai Raya Kecamatan Sungai Raya Kabupaten Aceh Timur Tahun 2018

Berdasarkan Pekerjaan

\begin{tabular}{clcc}
\hline No & Pekerjaan & $\begin{array}{c}\text { Frekuensi } \\
(\mathbf{f})\end{array}$ & $\begin{array}{c}\text { Persentase } \\
(\boldsymbol{\%})\end{array}$ \\
\hline 1 & Bekerja & 33 & 34,7 \\
2 & Tidak Bekerja & 62 & 65,3 \\
\hline \multicolumn{2}{c}{ Total } & $\mathbf{9 5}$ & $\mathbf{1 0 0}$ \\
\hline
\end{tabular}

Sumber data primer (Diolah Tahun 2018)

Tabel diatas menunjukkan bahwa dari 95 Pasangan Usia Subur (PUS) (100\%) mayoritas tidak bekerja yaitu sebanyak 62 responden $(65,3 \%)$.

Tabel 6. Distribusi Frekuensi Karakteristik Pasangan Usia Subur (PUS) di Wilayah Kerja UPT Puskesmas Sungai Raya Kecamatan Sungai Raya Kabupaten Aceh Timur Tahun 2018 Berdasarkan Pendapatan

\begin{tabular}{ccccc}
\hline \multirow{2}{*}{ No } & & Pendapatan & $\begin{array}{c}\text { Frekuensi } \\
(\mathbf{f})\end{array}$ & $\begin{array}{c}\text { Persentase } \\
(\boldsymbol{\%})\end{array}$ \\
\hline 1 & Tinggi & & 37 & 38,9 \\
2 & Rendah & & 58 & 61,1 \\
\hline \multicolumn{2}{c}{ Total } & $\mathbf{9 5}$ & $\mathbf{1 0 0}$ \\
\hline
\end{tabular}

Sumber data primer (Diolah Tahun 2018)

Tabel diatas menunjukkan bahwa dari 95 Pasangan Usia Subur (PUS) (100\%) mayoritas memiliki pendapatan rendah yaitu sebanyak 58 responden $(61,1 \%)$. 
Tabel 7. Distribusi Frekuensi Karakteristik Pasangan Usia Subur (PUS) di Wilayah Kerja UPT Puskesmas Sungai Raya Kecamatan Sungai Raya Kabupaten Aceh Timur Tahun 2018 Berdasarkan Paritas

\begin{tabular}{clcc}
\hline No & Paritas & $\begin{array}{c}\text { Frekuensi } \\
(\mathbf{f})\end{array}$ & $\begin{array}{c}\text { Persentase } \\
(\mathbf{\%})\end{array}$ \\
\hline 1 & Aman & 56 & 58,9 \\
2 & Tidak Aman & 39 & 41,1 \\
\hline \multicolumn{2}{c}{ Total } & $\mathbf{9 5}$ & $\mathbf{1 0 0}$ \\
\cline { 2 - 3 }
\end{tabular}

Tabel diatas menunjukkan bahwa dari 95 Pasangan Usia Subur (PUS) (100\%) mayoritas dengan paritas aman yaitu sebanyak 56 responden $(58,9 \%)$.

Tabel 8. Distribusi Frekuensi Hubungan Sikap Pasangan Usia Subur (PUS) dengan Keikutsertaan dalam Program KB di Wilayah Kerja UPT Puskesmas Sungai Raya Kecamatan Sungai Raya Kabupaten Aceh Timur Tahun 2018

\begin{tabular}{|c|c|c|c|c|c|c|c|c|}
\hline \multirow{3}{*}{ No } & \multirow{3}{*}{ Sikap } & \multicolumn{6}{|c|}{$\begin{array}{c}\text { Keikutsertaan PUS dalam } \\
\text { Program KB }\end{array}$} & \multirow{3}{*}{$\begin{array}{c}\mathbf{P} \\
\text { Value }\end{array}$} \\
\hline & & \multicolumn{2}{|c|}{$\mathbf{Y a}$} & \multicolumn{2}{|c|}{ Tidak } & \multicolumn{2}{|c|}{ Jumlah } & \\
\hline & & $\mathbf{F}$ & $\%$ & $\mathbf{F}$ & $\%$ & $\mathbf{F}$ & $\%$ & \\
\hline 1 & Positif & 57 & 60,0 & 8 & 8,4 & 65 & 68,4 & \multirow{2}{*}{0,000} \\
\hline \multirow[t]{2}{*}{2} & Negatif & 10 & 10,5 & 20 & 21,1 & 30 & 31,6 & \\
\hline & Jumlah & 67 & 70,5 & 28 & 29,5 & 95 & 100 & \\
\hline $\mathrm{df}=$ & & & $P<0$ & & & & & $=0,000$ \\
\hline
\end{tabular}

Sumber data primer (Diolah Tahun 2018)

Tabel diatas menunjukkan bahwa dari 95 Pasangan Usia Subur (PUS) (100\%) terdapat 65 yang bersikap positif mayoritas ikut serta dalam program KB yaitu sebanyak 57 responden $(60,0 \%)$.

Tabel 9. Hubungan Karakteristik Pasangan Usia Subur (PUS) dengan Keikutsertaan dalam Program KB di Wilayah Kerja UPT Puskesmas Sungai Raya Kecamatan Sungai Raya Kabupaten Aceh Timur Tahun 2018 Berdasarkan Usia

\begin{tabular}{|c|c|c|c|c|c|c|c|c|}
\hline \multirow{3}{*}{ No } & \multirow{3}{*}{ Usia } & \multicolumn{6}{|c|}{ Keikutsertaan PUS dalam Program KB } & \multirow{3}{*}{$\underset{\text { Value }}{\mathbf{P}}$} \\
\hline & & \multicolumn{2}{|c|}{ Ya } & \multicolumn{2}{|c|}{ Tidak } & \multicolumn{2}{|c|}{ Jumlah } & \\
\hline & & $\mathbf{F}$ & $\%$ & $\mathbf{F}$ & $\%$ & $\mathbf{F}$ & $\%$ & \\
\hline 1 & Remaja Akhir & 15 & 15,8 & 12 & 12,6 & 27 & 28,4 & \multirow{4}{*}{$\mathbf{0 , 0 5 7}$} \\
\hline 2 & Dewasa Awal & 20 & 21,0 & 5 & 5,3 & 25 & 26,3 & \\
\hline 3 & Dewasa Akhir & 30 & 31,6 & 8 & 8,4 & 38 & 40,0 & \\
\hline 4 & Lansia Awal & 2 & 2,1 & 3 & 3,2 & 5 & 5,3 & \\
\hline & Jumlah & 67 & 70,5 & 28 & 29,5 & 95 & 100 & \\
\hline
\end{tabular}




$$
\text { df }=3 \quad \mathrm{P}<0,1 \quad \mathrm{P}=0,057
$$

Sumber data primer (Diolah Tahun 2018)

Tabel diatas menunjukkan bahwa dari 95 Pasangan Usia Subur (PUS) (100\%) terdapat 38 yang berusia remaja akhir mayoritas ikut serta dalam program KB yaitu sebanyak 30 responden $(31,6 \%)$.

Tabel 10. Hubungan Karakteristik Pasangan Usia Subur (PUS) dengan Keikutsertaan dalam Program KB di Wilayah Kerja UPT Puskesmas Sungai Raya Kecamatan Sungai Raya Kabupaten Aceh Timur Tahun 2018 Berdasarkan Pendidikan

\begin{tabular}{|c|c|c|c|c|c|c|c|c|}
\hline \multirow{3}{*}{ No } & \multirow{3}{*}{ Pendidikan } & \multicolumn{6}{|c|}{$\begin{array}{c}\text { Keikutsertaan PUS dalam } \\
\text { Program KB } \\
\end{array}$} & \multirow{3}{*}{$\begin{array}{c}\mathbf{P} \\
\text { Value }\end{array}$} \\
\hline & & \multicolumn{2}{|c|}{ Ya } & \multicolumn{2}{|c|}{ Tidak } & \multicolumn{2}{|c|}{ Jumlah } & \\
\hline & & $\mathbf{F}$ & $\%$ & $\mathbf{F}$ & $\%$ & $\mathbf{F}$ & $\%$ & \\
\hline 1 & Tinggi & 25 & 26,3 & 1 & 1,1 & 26 & 27,4 & \multirow{3}{*}{0,001} \\
\hline 2 & Menengah & 28 & 29,5 & 13 & 13,7 & 41 & 43,2 & \\
\hline 3 & Dasar & 14 & 14,7 & 14 & 14,7 & 28 & 29,5 & \\
\hline & Jumlah & 67 & 70,5 & 28 & 29,5 & 95 & 100 & \\
\hline umb & 1 & & $\mathrm{P}<0$ & & & & & 0,001 \\
\hline
\end{tabular}

Tabel diatas menunjukkan bahwa dari 95 Pasangan Usia Subur (PUS) (100\%) terdapat 41 yang berpendidikan menengah mayoritas ikut serta dalam program KB yaitu sebanyak 28 responden $(29,5 \%)$.

Tabel 11. Hubungan Karakteristik Pasangan Usia Subur (PUS) dengan Keikutsertaan dalam Program KB di Wilayah Kerja UPT Puskesmas Sungai Raya Kecamatan Sungai Raya Kabupaten Aceh Timur Tahun 2018 Berdasarkan Pekerjaan

\begin{tabular}{|c|c|c|c|c|c|c|c|c|}
\hline \multirow{3}{*}{ No } & \multirow{3}{*}{ Pekerjaan } & \multicolumn{6}{|c|}{ Keikutsertaan PUS dalam } & \multirow{3}{*}{$\begin{array}{c}\mathbf{P} \\
\text { Value }\end{array}$} \\
\hline & & \multicolumn{2}{|c|}{ Ya } & \multicolumn{2}{|c|}{ Tidak } & \multicolumn{2}{|c|}{ Jumlah } & \\
\hline & & $\mathbf{F}$ & $\%$ & $\mathbf{F}$ & $\%$ & $\mathbf{F}$ & $\%$ & \\
\hline 1 & Bekerja & 29 & 30,5 & 4 & 4,2 & 33 & 34,7 & \multirow{2}{*}{$\mathbf{0 , 0 1 4}$} \\
\hline 2 & Tidak Bekerja & 38 & 40,0 & 24 & 25,3 & 62 & 65,3 & \\
\hline & Jumlah & 67 & $\mathbf{7 0 , 5}$ & 28 & 29,5 & 95 & 100 & \\
\hline
\end{tabular}

Sumber data primer (Diolah Tahun 2018) 
Tabel diatas menunjukkan bahwa dari 95 Pasangan Usia Subur (PUS) (100\%) terdapat 62 yang tidak bekerja mayoritas ikut serta dalam program KB yaitu sebanyak 38 responden $(40,0 \%)$.

Tabel 12. Hubungan Karakteristik Pasangan Usia Subur (PUS) dengan Keikutsertaan dalam Program KB di Wilayah Kerja UPT Puskesmas Sungai Raya Kecamatan Sungai Raya Kabupaten Aceh Timur Tahun 2018 Berdasarkan Pendapatan

\begin{tabular}{|c|c|c|c|c|c|c|c|c|}
\hline \multirow{3}{*}{ No } & \multirow{3}{*}{ Pendapatan } & \multicolumn{6}{|c|}{$\begin{array}{c}\text { Keikutsertaan PUS dalam } \\
\text { Program KB }\end{array}$} & \multirow{3}{*}{$\begin{array}{c}\mathbf{P} \\
\text { Value }\end{array}$} \\
\hline & & \multicolumn{2}{|c|}{ Ya } & \multicolumn{2}{|c|}{ Tidak } & \multicolumn{2}{|c|}{ Jumlah } & \\
\hline & & $\mathbf{F}$ & $\%$ & $\mathbf{F}$ & $\%$ & $\mathbf{F}$ & $\%$ & \\
\hline 1 & Tinggi & 33 & 34,7 & 4 & 4,2 & 37 & 38,9 & \multirow{2}{*}{$\mathbf{0 , 0 0 3}$} \\
\hline 2 & Rendah & 34 & 35,8 & 24 & 25,3 & 58 & 61,1 & \\
\hline & Jumlah & 67 & 70,5 & 28 & 29,5 & 95 & 100 & \\
\hline
\end{tabular}

Sumber data primer (Diolah Tahun 2018)

Tabel diatas menunjukkan bahwa dari 95 Pasangan Usia Subur (PUS) (100\%) terdapat 58 yang memiliki pendapatan rendah mayoritas ikut serta dalam program KB yaitu sebanyak 34 responden $(35,8 \%)$.

Tabel 13. Hubungan Karakteristik Pasangan Usia Subur (PUS) dengan Keikutsertaan dalam Program KB di Wilayah Kerja UPT Puskesmas Sungai Raya Kecamatan Sungai Raya Kabupaten Aceh Timur Tahun 2018 Berdasarkan Paritas

\begin{tabular}{|c|c|c|c|c|c|c|c|c|}
\hline \multirow{3}{*}{ No } & \multirow{3}{*}{ Paritas } & \multicolumn{6}{|c|}{$\begin{array}{c}\text { Keikutsertaan PUS dalam } \\
\text { Program KB }\end{array}$} & \multirow{3}{*}{$\begin{array}{c}\mathbf{P} \\
\text { Value }\end{array}$} \\
\hline & & \multicolumn{2}{|c|}{ Ya } & \multicolumn{2}{|c|}{ Tidak } & \multicolumn{2}{|c|}{ Jumlah } & \\
\hline & & $\mathbf{F}$ & $\%$ & $\mathbf{F}$ & $\%$ & $\mathbf{F}$ & $\%$ & \\
\hline 1 & Aman & 48 & 50,5 & 8 & 8,4 & 56 & 58,9 & \multirow{2}{*}{0,000} \\
\hline 2 & Tidak Aman & 19 & 20,0 & 20 & 21,1 & 39 & 41,1 & \\
\hline & Jumlah & 67 & 70,5 & 28 & 29,5 & 95 & 100 & \\
\hline$f=$ & & \multicolumn{4}{|c|}{$P<0,1$} & \multicolumn{3}{|c|}{$P=0,000$} \\
\hline
\end{tabular}

Sumber data primer (Diolah Tahun 2018)

Tabel diatas menunjukkan bahwa dari 95 Pasangan Usia Subur (PUS) (100\%) terdapat 56 dengan paritas aman mayoritas ikut serta dalam program KB yaitu sebanyak 48 responden $(50,5 \%)$. 
Hasil penelitian ini sejalan dengan hasil penelitian yang dilakukan oleh Arifah Istiqomah (2014) berjudul Faktor-Faktor Yang Memengaruhi Ketidakikutsertaan Penggunaan Alat Kontrasepsi Pada Pasangan Usia Subur, menyimpulkan bahwa variabel sikap merupakan salah satu faktor yang memengaruhi keikutsertaan penggunaan alat kontrasepsi pada pasangan usia subur.

Menurut Darmadi (2017), sikap (attitude) merupakan suatu kecenderungan untuk bereaksi dengan cara tertentu terhadap suatu perangsang atau situasi yang dihadapinya. Dalam hal ini sikap merupakan penentuan penting dalam tingkah laku manusia untuk bereaksi. Oleh karena itu, orang yang memiliki sikap positif terhadap suatu objek atau situasi tertentu ia akan memperlihatkan kesukaan atau kesenangan (like), sebaliknya orang yang memiliki sikap negatif ia akan memperlihatkan ketidaksukaan atau ketidaksenangan (dislike).

Menurut Notoatmodjo (2014), dalam menentukan sikap, pengetahuan, pikiran, keyakinan dan emosi memegang peranan penting. Sikap terdiri dari berbagai tingkatan, yaitu: menerima, yang diartikan bahwa orang (subjek) mau dan memperhatikan stimulus yang diberikan (objek). Merespon, yang diartikan orang (subjek) mau memberikan jawaban apabila ditanya, mengerjakan dan menyelesaikan tugas yang diberikan. Menghargai, yang diartikan orang (subjek) mau mengajak orang lain untuk mengerjakan atau mendiskusikan suatu masalah yang diberikan dan bertanggung jawab, yang diartikan orang (subjek) mau bertanggung jawab atas segala sesuatu yang telah dipilihnya dengan segala risiko.

Sikap positif Pasangan Usia Subur (PUS) dalam penelitian ini dapat diartikan bahwa Pasangan Usia Subur (PUS) mau menerima dan memperhatikan stimulus yang diberikan oleh tenaga kesehatan khususnya bidan pada saat penyuluhan mengenai program KB. Selanjutnya Pasangan Usia Subur (PUS) memberikan respon dengan mengikuti anjuran yang diberikan oleh tenaga kesehatan khususnya bidan untuk menggunakan salah satu metode kontrasepsi. Ketika Pasangan Usia Subur (PUS) tersebut merasa cocok dan nyaman menggunakan salah satu dari metode kontrasepsi, maka iapun mendiskusikan hal tersebut (tentang kecocokan dan kenyamanannya pada salah satu metode kontrasepsi) dan berusaha memberikan pandangan bahwa metode kontrasepsi yang dipakainya bagus. Selanjutnya Pasangan Usia Subur (PUS) tersebut akan mau bertanggung jawab atas segala sesuatu yang dianggapnya bagus tersebut, meskipun mendapatkan tantangan dari lingkungan-lingkungan di sekitarnya.

Sikap positif pasangan usia subur terhadap keikutsertaan dalam program KB diharapkan dapat memengaruhi pasangan usia subur lainnya (disekitarnya) agar turut serta dalam program 
KB. Dengan demikian, tidak akan ada lagi pasangan usia subur yang tidak mengikuti program KB. Sehingga dapat membentuk keluarga yang berkualitas.

Penelitian ini mengasumsikan bahwa adanya hubungan sikap Pasangan Usia Subur (PUS) dengan keikutsertaan dalam program KB di Wilayah Kerja UPT Puskesmas Sungai Raya Kecamatan Sungai Raya Kabupaten Aceh Timur tahun 2018 dikarenakan sikap menunjukkan kecenderungan untuk bereaksi terhadap situasi yang dihadapi (memperlihatkan kesukaan atau kesenangan). Sehingga ketika Pasangan Usia Subur (PUS) sudah menyukai hal terkait program KB maka ia memberikan reaksi yaitu ikut serta dalam program KB. Tingkah laku untuk ikut serta tersebut terbentuk karena adanya perasaan suka atau senang terhadap keinginan membentuk keluarga yang berkualitas. Oleh karena itu, kepada pemegang program KB di UPT Puskesmas Sungai Raya Kecamatan Sungai Raya Kabupaten Aceh Timur agar mengajak tokoh lintas sektor agar mengadakan pertemuan untuk membuat rencana loka karya mini setidaknya satu bulan sekali sehingga tidak ada lagi Pasangan Usia Subur (PUS) yang tidak mau menggunakan alat kontrasepsi.

\section{Hubungan Karakteristik Pasangan Usia Subur (PUS) dengan Keikutsertaan dalam Program KB di Wilayah Kerja UPT Puskesmas Sungai Raya Kecamatan Sungai Raya Kabupaten Aceh Timur Tahun 2018}

Hasil analisis univariat pada variabel karakteristik menunjukkan bahwa mayoritas Pasangan Usia Subur (PUS) berusia dewasa akhir dan minoritas berusia lansia awal. Mayoritas Pasangan Usia Subur (PUS) berpendidikan menengah dan minoritas berpendidikan tinggi. Mayoritas Pasangan Usia Subur (PUS) tidak bekerja. Mayoritas Pasangan Usia Subur (PUS) memiliki pendapatan rendah dan mayoritas Pasangan Usia Subur (PUS) dengan paritas aman.

Hasil analisis bivariat pada variabel karakteristik dan variabel Keikutsertaan dalam Program KB menunjukkan bahwa Pasangan Usia Subur (PUS) yang berusia remaja akhir mayoritas ikut serta dalam program KB. Pasangan Usia Subur (PUS) yang berpendidikan menengah mayoritas ikut serta dalam program KB. Pasangan Usia Subur (PUS) yang tidak bekerja mayoritas ikut serta dalam program KB. Pasangan Usia Subur (PUS) yang memiliki pendapatan rendah mayoritas ikut serta dalam program KB dan Pasangan Usia Subur (PUS) dengan paritas aman mayoritas ikut serta dalam program KB. Keseluruhan hasil uji statistik menunjukkan bahwa Ada Hubungan Karakteristik Pasangan Usia Subur (PUS) dengan 
Keikutsertaan dalam Program KB di Wilayah Kerja UPT Puskesmas Sungai Raya Kecamatan Sungai Raya Kabupaten Aceh Timur Tahun 2018.

Hasil penelitian ini sejalan dengan hasil penelitian yang dilakukan oleh Nurafni (2013) yang menyimpulkan bahwa adanya hubungan yang signifikan antara pendidikan ibu dengan tidak mengikuti program keluarga berencana dengan nilai probabilitas (p) 0,008. hasil penelitian ini juga sejalan dengan hasil penelitian yang dilakukan oleh Arifah Istiqomah (2014) yang menyimpulkan bahwa pendidikan, pekerjaan dan paritas merupakan faktor yang memengaruhi keikutsertaan penggunaan alat kontrasepsi pada pasangan usia subur.

Pasangan Usia Subur (PUS) yang berusia dewasa akhir (26-45 tahun) dan lansia awal (46-55 tahun) umumnya sudah berpengalaman dalam menggunakan metode kontrasepsi. Pasangan Usia Subur (PUS) pada usia ini lebih dapat memilih metode kontrasepsi yang dibutuhkan. Usia dalam pengaruhnya dengan pemakaian KB berperan sebagai faktor intrinsik. Semakin bertambah usia seseorang, semakin berkembang pula daya tangkap dan pola pikir sehingga pengetahuan yang diperoleh semakin baik. Semakin cukup umur maka tingkat kematangan dan kekuatan seseorang lebih matang dalam berfikir dan melakukan tindakan.

Pasangan Usia Subur (PUS) yang berpendidikan dasar (tingkat pendidikan rendah), keikutsertaannya dalam KB adalah untuk mengatur kelahiran. Sementara itu Pasangan Usia Subur (PUS) yang berpendidikan menengah dan tinggi (tingkat pendidikan tinggi), keikutsertaannya dalam KB untuk mengatur kelahiran dan meningkatkan kesejahteraan keluarga. Hal ini dikarenakan seseorang dengan tingkat pendidikan lebih tinggi memiliki pandangan yang lebih luas tentang suatu hal dan lebih mudah untuk menerima ide atau cara kehidupan baru. Pendidikan merupakan salah satu faktor yang menentukan pemilihan suatu metode kontrasepsi karena tingkat pendidikan yang lebih tinggi mampu menyerap informasi dan lebih mampu mempertimbangkan hal-hal yang menguntungkan atau efek samping bagi kesehatan yang berhubungan dengan pemakaian suatu metode kontrasepsi. Pendidikan diperlukan untuk mendapatkan informasi yang menunjang kesehatan sehingga dapat meningkatkan kualitas hidup.

Pasangan Usia Subur (PUS) yang bekerja cenderung memilih KB yang tidak menganggu aktivitas pekerjaannya. Hal ini terkait dengan ketidakinginan dari Pasangan Usia Subur (PUS) yang bekerja, terganggu pendapatan atau penghasilannya. Pasangan Usia Subur (PUS) yang bekerja cenderung tidak memilih pil yang pemakaiannya diwajibkan rutin dengan jangka pendek. Begitu juga dengan pendapatan yang merupakan sumber penghasilan 
seseorang untuk memenuhi kebutuhan sehari-hari. Dengan bekerja seseorang akan mendapatkan uang. Uang yang diperoleh dari hasil bekerja tersebut digunakan untuk memenuhi kebutuhan hidup.

Pasangan Usia Subur (PUS) dengan paritas aman mayoritas ikut serta dalam program KB, begitu juga sebaliknya Pasangan Usia Subur (PUS) dengan paritas tidak aman mayoritas tidak ikut serta dalam program KB. Pasangan Usia Subur (PUS) yang memiliki jumlah anak lebih banyak kemungkinan untuk memulai kontrasepsi lebih besar dibandingkan daripada Pasangan Usia Subur (PUS) yang mempunyai anak lebih sedikit. Jumlah anak mulai diperhatikan setiap keluarga karena semakin banyak anak semakin banyak pula tanggungan kepala keluarga dalam mencukupi kebutuhan materil selain itu juga untuk menjaga kesehatan sistem reproduksi karena semakin sering melahirkan semakin rentan terhadap kesehatan ibu. Jumlah anak hidup yang dimiliki seorang ibu, akan memberikan pengalaman dan pengetahuan, sehingga ibu dapat mengambil keputusan yang tepat tentang cara atau alat kontrasepsi yang akan dipakai, sehingga lebih cenderung untuk memilih metode kontrasepsi.

\section{KESIMPULAN}

1. Mayoritas Pasangan Usia Subur (PUS) ikut serta dalam program KB yaitu sebanyak 67 responden $(70,5 \%)$.

2. Secara Statistik Ada Hubungan Sikap Pasangan Usia Subur (PUS) dengan Keikutsertaan dalam Program KB di Wilayah Kerja UPT Puskesmas Sungai Raya Kecamatan Sungai Raya Kabupaten Aceh Timur Tahun 2018 dengan $p$ value 0,000 $(\mathrm{P}<0,1)$.

3. Secara Statistik Ada Hubungan Karakteristik Pasangan Usia Subur (PUS) dengan Keikutsertaan dalam Program KB di Wilayah Kerja UPT Puskesmas Sungai Raya Kecamatan Sungai Raya Kabupaten Aceh Timur Tahun 2018 dengan $p$ value $<0,1$.

\section{SARAN}

1. Kepada Pasangan Usia Subur (PUS) di Wilayah Kerja UPT Puskesmas Sungai Raya Kecamatan Sungai Raya Kabupaten Aceh Timur agar lebih sering dan rutin menghadiri kegiatan penyuluhan yang diselenggarakan oleh tenaga kesehatan khususnya terkait program KB agar dapat memilih dan menentukan metode kontrasepsi yang cocok untuk digunakan.

2. Kepada pemegang program KB di UPT Puskesmas Sungai Raya Kecamatan Sungai Raya Kabupaten Aceh Timur agar mengajak tokoh lintas sektor agar mengadakan pertemuan 
untuk membuat rencana loka karya mini setidaknya satu bulan sekali sehingga tidak ada lagi Pasangan Usia Subur (PUS) yang tidak mau menggunakan alat kontrasepsi.

3. Kepada peneliti selanjutnya yang akan melakukan penelitian terkait Keikutsertaan Pasangan Usia Subur (PUS) dalam Program KB agar menggunakan metode penelitian yang dapat menggali informasi lebih dalam tentang Keikutsertaan Pasangan Usia Subur (PUS) dalam Program KB seperti menggunakan metode wawancara secara tidak terstruktur untuk menggali lebih dalam apa yang menyebabkan Keikutsertaan Pasangan Usia Subur (PUS) dalam Program KB.

\section{DAFTAR PUSTAKA}

BKKBN Provinsi Aceh. (2016). Rapat Pengendalian Program (Radalgram). Diambil dari https:// nad.bkkbn.go.id/data/Documents/RADALGRAM\%20MARET\%202016.pdf. Diakses oleh: Ainul Mardhiah. 14 April 2018. 14.00 wib.

BKKBN. (2014). Pedoman Penyelenggaraan Pelayanan Keluarga Berencana Dalam Jaminan Kesehatan Nasional. Jakarta: Ditjalpem Badan Kependudukan dan Keluarga Berencana Nasional.

BKKBN. (2017). Info Demografi 2017 BKKBN. Jakarta: LD-FE Universitas Indonesia.

BPS. (2017). Statistik Indonesia 2017 (Statistical Yearbook of Indonesia 2017). Jakarta: Badan Pusat Statistik.

Darmawati. (2017). Keikutsertaan Menjadi Akseptor Keluarga Berencana pada Pasangan Usia Subur Ditinjau dari Aspek Sosial dan Budaya. Idea Nursing Journal Bagian Keilmuan Keperawatan Maternitas Fakultas Keperawatan Universitas Syiah Kuala Banda Aceh Vol. VIII No. 12017.

Dewi, Putri Hariyani Chandra. (2014). Rendahnya Keikutsertaan Pengguna Metode Kontrasepsi Jangka Panjang Pada Pasangan Usia Subur. Jurnal Biometrika dan Kependudukan Fakultas Kesehatan Masyarakat Universitas Airlangga, Vol. 3, No. 1 Juli 2014.

Hestanto. (2017). Pengertian Pendapatan. Diambil dari http://www.hestanto.web.id/pengertian-pendapatan/. Diakses oleh: Ainul Mardhiah. 6 Mei 2018. 11.00 wib.

Hidayat, Wahyu. (2015). Pengertian Karakteristik Secara Umum. Diambil dari https://www.trendilmu.com/2015/06/pengertian-karakteristik-secara-umum.html\#. Diakses oleh: Ainul Mardhiah. 5 Mei 2018. 19.30 wib.

Istiqomah, Arifah. (2014). Faktor-Faktor Yang Mempengaruhi Ketidakikutsertaan Penggunaan Alat Kontrasepsi Pada Pasangan Usia Subur. Jurnal Kesehatan Akademi Kebidanan Ummi Khasanah, Jl. Pemuda Gandekan Bantul. 
Kemenkes RI. (2016). Profil Kesehatan Indonesia Tahun 2015. Jakarta: Kesehatan Kementerian Kesehatan Republik Indonesia.

Kemenkes RI. (2017). Profil Kesehatan Indonesia Tahun 2016. Jakarta: Kementerian Kesehatan Republik Indonesia.

Kurniawati, T. (2014). Buku Ajar Kependudukan dan Pelayanan KB. Jakarta: EGC.

Maulana, Angga. (2017). Kelebihan dan Kekurangan Berbagai Alat Kontrasepsi. Diambil dari https://hellosehat.com/kelebihan-dan-kekurangan-berbagai-alat-kontrasepsi/. Diakses oleh: Ainul Mardhiah. 5 Mei 2018. 16.00 wib.

Muhammad, Iman. (2013). Panduan Penyusunan Karya Tulis Ilmiah Bidang Kesehatan. Bandung: Citapustaka Media Perintis.

Muhammad, Iman. (2014). Pemanfaatan SPSS Dalam Penelitian Bidang Kesehatan \& Umum. Bandung: Citapustaka Media Perintis.

Nanda. (2013). Diagnosis Keperawatan. Jakarta: EGC

Nurafni. (2013). Hubungan Karakteristik Pasangan Usia Subur yang Tidak Mengikuti Program Keluarga Berencana di Desa Reudep Melayu Kecamatan Glumpang Tiga Kabupaten Pidie. Karya Tulis Ilmiah Program Studi Diploma III Kebidanan Sekolah Tinggi Ilmu Kesehatan U'budiyah Banda Aceh.

Peraturan Gubernur Aceh Nomor 67 Tahun 2017 tentang Penetapan Upah Minimum Provinsi Aceh Tahun 2018.

Pinem, S. (2014). Kesehatan Reproduksi dan Kontrasepsi. Jakarta: KDT.

Puspitasari, Dwi. (2014). Dukungan Keluarga dalam Keikutsertaan KB pada Pasangan Usia Subur di Desa Argomulyo Sedayu Bantul Yogyakarta. Jurnal Ners dan Kebidanan Indonesia Sekolah Tinggi Ilmu Kesehatan Alma Ata Yogyakarta.

Sulistyawati, A. (2013). Pelayanan Keluarga Berencana. Jakarta: Salemba Medika.

USAID. (2018). Family Planning Programming. Diambil dari https://www.globalhealthlearning.org/program/family-planning-and-reproductivehealth. Diakses oleh: Ainul Mardhiah. 8 April 2018. 08.30 wib.

Zulkifly, Dicky. (2016). 73,46 Persen, Keikutsertaan KB Purwakarta Tertinggi di Jawa Barat. Diambil dari http://www.headlinejabar.com/jabar/1260-73,46-persen,keikutsertaan-kb-purwakarta-tertinggi-di-jawa-barat. Diakses oleh: Ainul Mardhiah. 6 Mei 2018. 09.00 wib. 